\title{
Induction and identification of Stylosanthes guianensis tetraploids
}

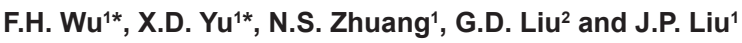 \\ ${ }^{1}$ College of Agronomy, Hainan University, Haikou, Hainan Province, China \\ ${ }^{2}$ Institute of Tropical Crops Genetic Resources, \\ Chinese Academy of Tropical Agricultural Sciences, Danzhou, Hainan Province, \\ China
}

*These authors contributed equally to this study.

Corresponding author: J.P. Liu

E-mail: liu3305602@163.com

Genet. Mol. Res. 14 (4): 12692-12698 (2015)

Received March 25, 2015

Accepted July 7, 2015

Published October 19, 2015

DOI http://dx.doi.org/10.4238/2015.October.19.13

ABSTRACT. Stylosanthes guianensis is an elite and important forage legume species, which is extensively cultivated in tropical areas. Polyploid breeding via exposure to colchicine is a conventional and practical method to improve varieties of $S$. guianensis. Terminal buds of S. guianensis Reyan No.5 seedlings were treated with different concentrations of colchicine $(0.00,0.05,0.10,0.15,0.20$, and $0.25 \%)$ for 24,48 , and $72 \mathrm{~h}$. Morphological and cytological variants were observed at a frequency of $<96 \%$ among transplanted seedlings. The cytogenetic analysis of young leaf cells was conducted on all variants to identify their ploidy levels. The most efficient procedure for tetraploid production was the treatment of seedling apical buds with $20 \%$ colchicine for $48 \mathrm{~h}$, with the tetraploid induction rate being $10 \%$. This is a relatively simple and reliable method for the production of tetraploidy in S. guianensis.

Key words: Stylosanthes guianensis; Tetraploid induction; Colchicine; Polyploid identification 


\section{INTRODUCTION}

Stylosanthes guianensis (Aubl.) Sw., is a perennial herb native to South and Central America, and is the most widespread Stylosanthes species (Chandra et al., 2006; Chandra 2013). As a member of the genus Stylosanthes, it encompasses many advantages of legumes as forage such as the ability to restore soil fertility, improve soil physical properties, and provide permanent vegetation cover (Chandra, 2013). In China, S. guianensis is widely cultivated because it is valued as a high-productivity tropical forage crop with high nutritive value, it is adaptive to poor and acrid soils, and is tolerant of drought and disease (Yi, 2001). S. guianensis is diploid $(2 n=2 x=20)$ and predominantly self-pollinating with a low degree of out-crossing (Stace, 1982; Stace and Edye, 1984). When breeding S. guianensis, the limited variations of available germplasm is a problem (Chandra, 2013).

Chromosome doubling is a valuable tool used in plant breeding to obtain useful characteristics, such as increased organ size, including leaves, high productivity and quality, and high levels of resistance to stresses. In addition, induced polyploid breeding provides a wider germplasm base for breeding programs (Luckett, 1989; Aranada et al., 1997; Osborn et al., 2003; Shao et al., 2003; Thao et al., 2003; Comai, 2005; Omidbaigi et al., 2010). By preventing microtubule assembly and arresting spindle formation during mitosis, colchicine is conventionally and successfully used to induce chromosome doubling in the development of tetraploids (Takamura and Miyajima, 1996; Pinheiro et al., 2000; Nguyen et al., 2003; Petersen et al., 2003; Shao et al., 2003; Liu et al., 2007; Urwin et al., 2007).

\section{MATERIAL AND METHODS}

\section{Plant Material}

Fresh seeds of S. guianensis Reyan No. 5 were supplied by the Institute of Tropical Crop Genetic Resources, Chinese Academy of Tropical Agricultural Sciences (CATAS). First, the seeds were immersed in cold water for $0.5 \mathrm{~h}$, then in water heated to $80^{\circ} \mathrm{C}$ for $3-5 \mathrm{~min}$. Second, the seeds were sown in loam soil in seedling cups at room temperature for germination.

\section{Colchicine treatment}

Four-day-old plantlets were used for colchicine treatment. Colchicine solutions (Sinopharm Chemical Reagent Co., Ltd.) in final concentrations of $0.00,0.05,0.10,0.15,0.20$, and $0.25 \%(w / v)$ were dripped on apical buds of the seedling's emerging cotyledon leave and maintained for $24 \mathrm{~h}$, $48 \mathrm{~h}$, and $72 \mathrm{~h}$. After treatment, the leaves were rinsed with water four times. Control seedlings were similarly treated with distilled water and 50 seedlings were used in each treatment.

\section{Morphological and cytological observation of variants}

Seedlings were transplanted to the field one month after germination (April 2010) and morphological and cytological observations were carried out on vegetative parts of variants in August 2010. The diameter of 30 main stems (of the seventh internode from the terminal bud), the length, width, and thickness of 30 fully mature leaves (two leaves per plant), and the length and width of 30 petioles randomly selected from the variants and the control were measured with an electronic digital caliper (DC 1004, PLG-Discover, China) and recorded. In addition, a few pieces 
of epidermal layer torn from the abaxial side of mature leaves of the variants and the control were respectively mounted on a glass slide with one drop of aqueous solution of $1.0 \%$ iodine and $1.0 \%$ potassium iodide. The length and width of stomata were measured under an Olympus BX51 microscope (Olympus America Inc., NY, USA). The stomata density was also calculated.

The plants entered the full-bloom stage in mid-late October, 2010. The length of the 30 fully opened flowers and the width of 30 vexilla randomly selected from the variants and the control were determined. The shape and size of dry pollen between the variants and the control were compared under a light microscope. In late December 2010, the matured seeds were harvested and the thousand kernel weight was estimated. Statistical analysis was carried out using ANOVA to assess the difference between the variant and the control in SPPSS software (version 18.0). Significance of differences among means was determined by Duncan's multiple range test at $P \leq 0.0001,0.01$, or 0.05 .

\section{Chromosome counting}

All plants that showed variations were subjected to chromosome counting. Young leaves randomly selected from each variant were excised at $10.00 \mathrm{a} . \mathrm{m}$. and were pretreated in $0.002 \mathrm{~mol} / \mathrm{L}$ 8-hydroxyquinoline solution for $2 \mathrm{~h}$ at $4^{\circ} \mathrm{C}$. They were then washed three times in distilled water, fixed in Carnoy's solution for $7 \mathrm{~h}$ at $4^{\circ} \mathrm{C}$, and washed three times in distilled water. Subsequently, samples were hydrolyzed in $1 \mathrm{~mol} / \mathrm{L}$ hydrochloric acid solution for $3 \mathrm{~min}$ at room temperature and then washed five times. After staining with carbol fuchsin for about $20 \mathrm{~min}$, these prepared leaves were squashed under cover glass, their chromosome numbers were observed under a microscope through a $100 \mathrm{X}$ oil lens, and photos were taken with the associated apparatus. A plant with all the leaf cells showing 20 chromosomes was regarded as diploid and with all the cells showing 40 chromosomes was determined as tetraploid.

\section{RESULTS}

\section{The effects of colchicine on variations}

The occurrence of variations depended on the colchicine concentration and the duration of treatment. For treatment times of $24 \mathrm{~h}$ and $48 \mathrm{~h}$, the number and percent of variants increased with the concentration of colchicine (Table 1). When the seedlings were treated with colchicine for 72 $\mathrm{h}$, the largest number (48) and the highest rate (96\%) of variants were obtained at concentrations of $0.15 \%$. When the concentration of colchicine was greater than $0.15 \%$, the survival rate fell dramatically and the number and percentage of variants also declined.

\section{Morphological and cytological comparison of the diploid control and variants S. guianensis Reyan No.5}

The variants grew stronger and more slowly than the diploids, and the stems of the variants therefore appeared thicker than those of the controls (Figure 1A). The leaves of the variants were dark green, and were also bigger and thicker than those of the controls (Figure 1B). Cytological observation revealed that the stomata of the variants were larger than those of the diploids although the reverse was true for stomata density (Figure $1 \mathrm{C}-\mathrm{F}$ ). Whole flowers and flower parts of variants were bigger than those of the controls. There was also variation in the shape and size of pollen. 
The variants had small, relatively regular and long elliptic pollens, while those of the controls were larger and irregular (Figure $1 \mathrm{H}, \mathrm{I}$ ). Seeds of the variants were bigger and heavier than those of the controls. Analysis by $t$-test revealed that there were significant differences between the variants and the controls for each morphological and cytological indicator (Table 2).

Table 1. Effects of different colchicine treatments on Stylosanthes guianensis Reyan No. 5 seedlings.

\begin{tabular}{|c|c|c|c|c|}
\hline $\begin{array}{l}\text { Duration of } \\
\text { treatment }(\mathrm{h})\end{array}$ & $\begin{array}{c}\text { Colchicine } \\
\text { concentration (\%) }\end{array}$ & $\begin{array}{c}\text { No. of seedlings that } \\
\text { died after treatment (\%) }\end{array}$ & No. of variants ( \%) & No. of tetraploids (\%) \\
\hline \multirow[t]{6}{*}{24} & 0.00 & $0(0)$ & $0(0)$ & $0(0)$ \\
\hline & 0.05 & $0(0)$ & $2(4)$ & $0(0)$ \\
\hline & 0.10 & $0(0)$ & $7(14)$ & $0(0)$ \\
\hline & 0.15 & $0(0)$ & $12(24)$ & $0(0)$ \\
\hline & 0.20 & $0(0)$ & $30(60)$ & $0(0)$ \\
\hline & 0.25 & $0(0)$ & $33(66)$ & $0(0)$ \\
\hline \multirow[t]{6}{*}{48} & 0.00 & $0(0)$ & $0(0)$ & $0(0)$ \\
\hline & 0.05 & $0(0)$ & $6(12)$ & $0(0)$ \\
\hline & 0.10 & $0(0)$ & $12(24)$ & $0(0)$ \\
\hline & 0.15 & $0(0)$ & $18(36)$ & $0(0)$ \\
\hline & 0.20 & $2(4)$ & $38(76)$ & $5(10)$ \\
\hline & 0.25 & $2(4)$ & $42(84)$ & $2(4)$ \\
\hline \multirow[t]{6}{*}{72} & 0.00 & $0(0)$ & $0(0)$ & $0(0)$ \\
\hline & 0.05 & $0(0)$ & $6(12)$ & $0(0)$ \\
\hline & 0.10 & $0(0)$ & $20(40)$ & $1(2)$ \\
\hline & 0.15 & $0(0)$ & $48(96)$ & $1(2)$ \\
\hline & 0.20 & $8(16)$ & $40(80)$ & $0(0)$ \\
\hline & 0.25 & $10(20)$ & $37(74)$ & $0(0)$ \\
\hline
\end{tabular}
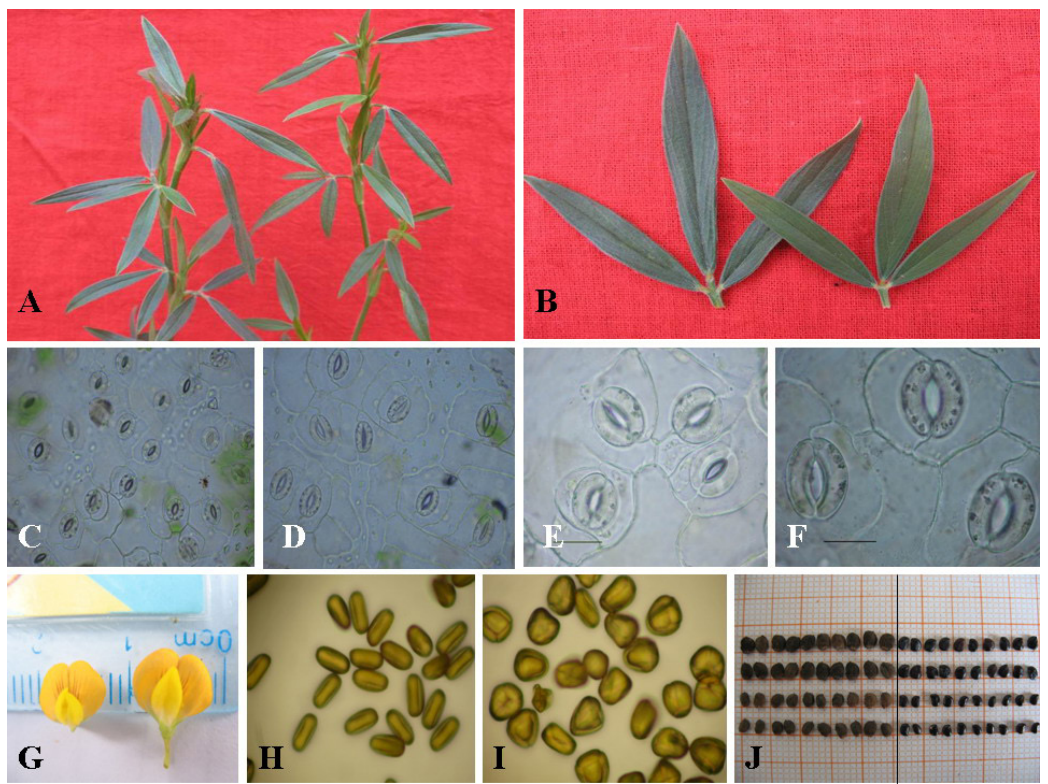

Figure 1. Morphological and cytological differences between control and variant Stylosanthes guianensis Reyan No.5 seedlings following treatment with colchicine solution. A. Variant (left) and diploid control plant (right); B. leaves of the variant (left) and diploid control plant (right); C, E. Stomata of the control, Bar $=20 \mu \mathrm{m} ; \mathbf{D}$, F. Stomata of the variant. Bar $=20 \mu \mathrm{m} ; \mathbf{G}$. The flowers of the variant (right) and the control plant (left); H. Dry pollen grains from the control; I. Dry pollen grains from the variant; J. Seeds from the variant (left) and the control plant (right). 
Table 2. Comparison of morphological and cytological characteristics between control and variant Stylosanthes guianensis Reyan No.5 seedlings following treatment with colchicine solution.

\begin{tabular}{|c|c|c|c|}
\hline Parts & Indictors & Controls & Variants \\
\hline Stem & Diameter (mm) & $2.37 \pm 0.16^{b}$ & $3.00 \pm 0.17^{\mathrm{a}}$ \\
\hline \multirow[t]{4}{*}{ Leaf } & Length (mm) & $31.98 \pm 4.16^{b}$ & $42.78 \pm 4.35^{\mathrm{a}}$ \\
\hline & Width $(\mathrm{mm})$ & $6.86 \pm 0.53^{b}$ & $7.44 \pm 0.57^{\mathrm{a}}$ \\
\hline & Thickness (mm) & $0.28 \pm 0.06^{b}$ & $0.34 \pm 0.06^{\mathrm{a}}$ \\
\hline & Leaf index (length/width) & $4.67 \pm 0.53^{b}$ & $5.76 \pm 0.58^{\mathrm{a}}$ \\
\hline \multirow[t]{2}{*}{ Petiole } & Length $(\mathrm{mm})$ & $8.55 \pm 0.33^{\mathrm{a}}$ & $7.21 \pm 0.29^{b}$ \\
\hline & Width $(\mathrm{mm})$ & $1.19 \pm 0.06^{\mathrm{b}}$ & $1.66 \pm 0.08^{a}$ \\
\hline \multirow[t]{3}{*}{ Stomata } & Width $(\mu \mathrm{m})$ & $15.79 \pm 1.97^{b}$ & $18.92 \pm 1.96^{a}$ \\
\hline & Length $(\mu \mathrm{m})$ & $22.34 \pm 1.55^{b}$ & $29.55 \pm 1.95^{\mathrm{a}}$ \\
\hline & Density (no. of stomata/mm²) & $370 \pm 50.52^{\mathrm{a}}$ & $165 \pm 30.97^{b}$ \\
\hline \multirow[t]{2}{*}{ Flower } & Length $(\mathrm{cm})$ & $0.71 \pm 0.02^{b}$ & $0.86 \pm 0.04^{a}$ \\
\hline & Width of vexilla $(\mathrm{cm})$ & $0.70 \pm 0.01^{\mathrm{b}}$ & $0.86 \pm 0.04^{\mathrm{a}}$ \\
\hline \multirow[t]{3}{*}{ Pollen } & Length $(\mu \mathrm{m})$ & $38.04 \pm 2.36^{b}$ & $45.64 \pm 3.45^{\mathrm{a}}$ \\
\hline & Width $(\mu \mathrm{m})$ & $33.51 \pm 1.89^{b}$ & $43.60 \pm 3.29^{a}$ \\
\hline & Pollen index (length/width) & $1.14 \pm 0.05^{\mathrm{a}}$ & $1.05 \pm 0.05^{b}$ \\
\hline Seed & Average weight $(\mathrm{g})$ of 20,000 seeds & $2.63 \pm 0.05^{b}$ & $3.32 \pm 0.03^{\mathrm{a}}$ \\
\hline
\end{tabular}

Each value shows the mean \pm SD from three experiments. Values within the same column followed by different letters are significantly different by the t-test $(P<0.01)$.

\section{Chromosome counting and tetraploid identification}

Chromosome counting was conducted for all variants. The results demonstrated that there was a concentration and exposure dependent increase in variation and mortality in seedlings following treatment with colchicine. Although the percent variation was highest (96\%) when the seedlings were exposed to $0.15 \%$ colchicine for $72 \mathrm{~h}$, the highest doubling efficiency was achieved with $0.20 \%$ colchicine for $48 \mathrm{~h}$ (Table 1). Cytogenetic identification revealed that tetraploid nuclei were bigger than diploid nuclei, and the chromosome number of diploid plants was $2 n=2 x=20$, whilst that of tetraploid plants was $2 n=4 x=40$ (Figure 2).
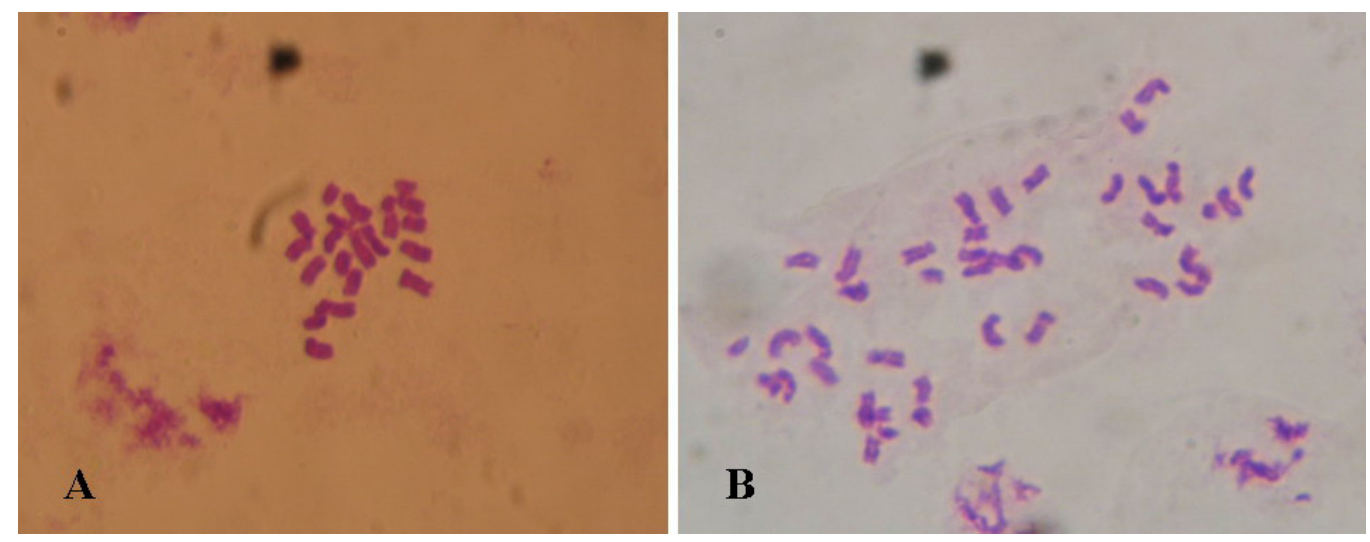

Figure 2. Chromosomes in young leaf cells of $(\mathbf{A})$, diploid $(2 n=2 x=20)$ and $(B)$, tetraploid $(2 n=4 x=40)$ plants.

\section{DISCUSSION}

Creation of polyploids is an important and effective method used in plant breeding, but there have been no reports about artificial induction of autopolyploids in $S$. guianensis. Our research 
indicated that treating the shoot-tips of seedlings with a suitable concentration of colchicine for an appropriate period of time could generate good results. The results indicated that colchicine had negative effects on the growth of seedlings following treatment. Toxic effects of colchicine were proportional to the concentration used and the exposure time (Roy et al., 2001; Trojak-Goluch and Skomra, 2013). Treatment with higher concentrations of colchicine for a longer time adversely affected the viability of the seedlings, while certain combinations of concentration and exposure time proved to be effective for tetraploid induction of S. guianensi, with the highest percentage of tetraploids recorded following treatment with $0.20 \%$ for $48 \mathrm{~h}$.

Previously, a preliminary study of the artificial induction of tetraploids in S. guianensis with seeds and calli was carried out in our laboratory, but the effectiveness was not satisfactory. High variation $(100 \%)$ in seedlings could be obtained by immersing S. guianensis seeds in colchicine solution, but the cytogenetic identification proved that the majority of seedlings were diploids and genetic chimera. The variable regenerative potential of calli and the difficulty of morphological identification of putative tetraploids of in vitro plants from their diploid counterparts limited the application of the in vitro induction system in S. guianensis. Therefore, induction of polyploidy with suitable materials is also crucial to obtain true polyploids.

Morphological and cytological characteristics such as changes in the stem, leaf, and flower, the size of stomata cells, stomata density, and pollen grain diameter were used as indirect indicators for ploidy determination (Blakeslee and Avery, 1937; Abak et al., 1998; Ajalin et al., 2002; Beck et al., 2003; Liu et al., 2007; Sun et al., 2009; Omidbaigi, 2010; Tang et al., 2010). Our results show that only a small proportion of variants possessing those traits were identified as tetraploids in S. guianensis. Most of the variants were diploid and chimeric plants. Therefore, those morphological and cytological indicators can be useful in the primary screening of putative polyploids, but may not sufficiently and reliably be used to estimate the ploidy level.

\section{Conflicts of interest}

The authors declare no conflict of interest.

\section{ACKNOWLEDGMENTS}

Research financially supported by the National Science Foundation of Hainan Province (\#312056), the Fundamental Research Funds for the Institute of Tropical Crops Genetic Resources, Chinese Academy of tropical Agriculture Sciences (CATAS) (\#PZS074) and the Integration and Demonstration of Key Technologies for Hainan Kapok Industry Development (\#cxy20140027).

\section{REFERENCES}

Abak K, Çömlekçioĝlu N, Büyükalaca S and Sari N (1998). Use of stomatal characteristics to estimate ploidy level of haploid and diploid pepper plants. Tenth Eucarpia meeting Capsicum and Eggplant, 7-11 September 1998, Avignon, France, 179-182.

Ajalin I, Kobza F and Dolzel J (2002). Ploidy identification of double chromosome number plants in Viola Wittrockiana Gams. M1-generation. Hort. Sci. 29: 35-40.

Aranada RR, Bondada BR, Syvertsen JP and Grosser JW (1997). Leaf characteristics and net gas exchange of diploid and autotetraploid Citrus. Ann. of Bot. 79: 153-160.

Beck SL, Dunlop RW and Fossey A (2003). Stomatal length and frequency a measure of ploidy level in black wattle, Acacia mearnssi (De Wild.). Bot. J. Linn. Soc. 141: 177-181. 
Blakeslee AF and Avery AG (1937). Methods of inducing doubling of chromosome in plants by treatment with colchicine. J. Herid. 28: 393-411.

Chandra A (2013). Biotechnology of Stylosanthes. In: Biotechnology of Neglected and Underutilized Crops. (Jain SM and Gupta SD (Eds.), Springer, 217-242.

Chandra A, Pathak PS and Bhatt RK (2006). Stylosanthes research in India: prospects and challenges ahead. Curr. Sci. 90: 915-921.

Comai $L$ (2005). The advantages and disadvantages of being polyploidy. Nat. Rev. Genet. 6: 836-846.

Liu G, Li Z and Bao M (2007). Colchicine-induced chromosome doubling in Platanus acerifolia and its effect on plant morphology. Euphytica 157: 145-154.

Luckett DJ (1989). Colchicine mutagenesis is associated with substantial heritable variation in cotton. Euphytica 42: $177-182$.

Nguyen T, Phuong T, Kenji U, Ikuo M, et al. (2003). Induction of tetraploids in ornamental Alocasia through colchicine and oryzalin treatments. Plant Cell Tiss. Organ Cult. 72: 19-25.

Omidbaigi R, Mirzaee M, Hassani ME and Moghadam MS (2010). Induction and identification of polyploidy in basil (Ocimum basilicum L.) medicinal plant by colchicine treatment. Int. J. Plant Prod. 4: 87-98.

Osborn TC, Pires JC, Birchler JA, Auger DL, et al. (2003). Understanding mechanisms of novel gene expression in polyploids. Trends Genet. 19: 141-147.

Pinheiro AA, Pozzobon MT, do Valle CB, Penteado MIO, et al. (2000). Duplication of the chromosome number of diploid Brachiaria brizantha plants using colchicines. Plant Cell Rep. 19: 274-278.

Petersen KK, Hagberg P and Kristiansen K (2003). Colchicine and oryzalin mediated chromosome doubling in different genotypes of Miscanthus sinensis. Plant Cell Tiss. Organ Cult. 73: 137-146.

Roy AT, Leggett G and Koutoulis A (2001). In vitro tetraploid induction and generation of tetraploids from mixoploids in hop (Humulus lupulus L.). Plant Cell Rep. 20: 489-495.

Shao J, Chen C and Deng X (2003). In vitro induction of tetraploid in pomegranate (Punica granatum). Plant Cell Tiss. Organ Cult. 75: 241-246.

Stace HM (1982). Breeding systems in Stylosanthes. I. Observations of outcrossing in S. scabra at an alcohol dehydrogenase locus. Australian J. Agricul. Res. 33: 87-96.

Stace HM and Cameron DF (1984). Cytogenetics and the evolution of Stylosanthes. In: The biology and agronomy of Stylosanthe (Stace HM and Edye LA, Eds.). New York, Academic Press, pp. 49-72.

Sun QR, Sun SH, Li LG and Bell RL (2009). In vitro colchicines induced polyploidy plantlet production and regeneration from leaf explants of the diploid pear (Pyrus communis L.) cultivar 'Fertility'. J. Hortic. Sci. Biotech. 84: 548-552.

Takamura T and Miyajima, I (1996). Colchicine induced tetraploids in yellow-flowered cyclamens and their characteristics. Sci. Hortic. 65: 305-312.

Tang ZQ, Chen DL, Song ZJ, He YC, et al. (2010). In vitro induction and identification of tetraploid plants of Paulownia tomentosa. Plant Cell Tiss. Organ Cult. 102: 213-220.

Thao NTP, Ureshino K, Miyajima I, Ozaki Y, et al. (2003). Induction of tetraploids in ornamental Alocasia through colchicine and oryzalin treatments. Plant Cell Tiss. Organ Cult. 72: 19-25.

Trojak-Goluch A and Skomra U (2013). Artificially induced polyploidization in Humulus lupulus L. and its effect on morphological and chemical traits. Breed. Sci. 63: 393-399.

Urwin NAR, Horsnell J and Moon T (2007). Generation and characterisation of colchicine-induced autotetraploid Lavandula angustifolia. Euphytica 156: 257-266.

Yi KX (2001). The development status, prospects and countermeasures of tropical forage industry in China. J. Trop. Agri. Sci. 4: $30-34$. 